\title{
Dani Karavan. Narracja form w krajobrazie miasta
}

\section{Dani Karavan. Narrative of forms in the cityscape}

Abstrakt

W artykule analizowana jest forma rzeźb Dani Karavana w kontekście przestrzeni miejskiej, w której obecne są zieleń i woda leń wykorzystywh przestrzennych izraelskiego rzeźbiarza wielkoskalowych interwencjach w przestrzeń publiczna - woda i zienymi elementami kraji brazu - wartósci symboliczn: upamietnienie wydarzé́ historycznych, czy wartości takich jak ochron środowiska nturalogo, tolerancia, prawa cztowieka. Elementarne formy architektoniczne, zieleń i woda u Karavana tworza spójny system narracyjny, podnoszący wartość ich otoczenia, kreujący genius loci

\section{Abstract}

The article analyses the form of Dani Karavan's sculptures in the context of urban space in which greenery and water are present. In the spatial compositions of the Israeli sculptor - large-scale interventions into the public space - water and greenery are used as constituent elements. In addition to aesthetic values, they - along with sculptural forms and other elements of the landscape - carry symbolic values: commemoration of historical events, or values such as environmental protection, tole rance and human rights. Elementary architectural forms, greenery and water, cre
works that increases the value of their surroundings and creates the genius loci.

Stowa kluczowe: Axe Majeur, Dani Karavan, Droga do Ukrytego Ogrodu, genius loci, Kikar Lewana, makom, narracja w architekturze, Pasaze whotdzie Walterowi Benjaminowi, Sinti and Roma Memorial

Homage to Walter Beniamin, Sinti and Roma Memorial

\section{Wprowadzenie}

Dani Karavan (ur. 1930) jest izraelskim rzeźbiarzem o polskich korzeniach, którego dzieła rozproszone są po całym świecie, przyjmując różne skale i formy - od niewielkich (np. Sinti Memorial w Berlinie2012) czasowych obiektów (jak Environment for Peace we Florencji, 1978), po wielkoskalowe instalacje (jak np. nieukończone Axe Majeur w podparyskim Cergy-Pontoise). Karavan działa wyłącznie w sferze publicznej, co nadaje jego dziełom wyraźnie zarysowany profil - miejsc komemoratywnych oraz przestrzeni kulturalnych. Do najważniejszych prac rzeźbiarza zaliczyć można: Monument to the Negev Brigade (1968, Negev, Beersheva), Kikar Levana (Hebrew for The White Plaza; 1988, Tel Aviv, Israel), The Way of Human Rights (1993, Germanisches Nationalmuseum, Nuremberg, Germany), Passage, a Homage to Walter Benjamin (1994, Portbou, Catalonia, Spain), Way to the Hidden Garden (1999, Sapporo Art Forest open-air gallery, Japan) czy wymienione już Memorial to the Sinti and Roma victims of National Socialism lub Axe majeur. Pełna lista twórczości obejmuje jednak około stu zrealizowanych projektów - stałych lub czasowych - roz-

\section{Introduction}

Dani Karavan (born 1930) is an Israeli sculptor with Polish roots, whose works are scattered all over the world, adopting various scales and forms - from small (e.g. The Sinti \& Roma Memorial in Berlin 2012) temporary structures (e.g. Two Environinstallations (such as the unfinished large-scale in Cergy-Pontoise near Paris). Karavan acts exclusively in the public sphere, which gives his works a clearly outlined profile - commemorative places and cultural spaces. The most important works of the sculptor include: Negev Monument (Beer Sheva in Israel, 1968), Kikar Levana (Hebrew for The White Square; Tel Aviv in Israel, 1988), Way of the Human Rights (Germanisches Nationalmuseum, Nuremberg in Germany, 1993), Passages, Homage to the Hidden Garden (Outdoor Scuin, 1994), Way to the Hidden Garden (Outdoor Sculpture Park The Sinti \& Roma Memorial and Axe Majeur. How ever, the full list of works amounts to about one hundred constructed projects - either permanen sianych po całym świecie. Zaznaczyć także należy żydowskie pochodzenie Daniego Karavana, Kore wplywa stanowi istotny na wkład kultury żydowskiej w jego prace.

Instalacje Karavana to przestrzeń o wyraźnie architektonicznym wyrazie. Sam rzeźbiarz określa swoją sztukę jako: rzeźba environmental-site-specific $z$ naturalnymi materiałami i wspomnieniami ${ }^{1}$. Jednocześnie, artysta zaznacza, że nie potrafi konkretnie przypisać swoich dzieł do jednej tylko dziedziny sztuki Plasuje je gdzieś pomiedzy" architektura, rzeźba i architektu-

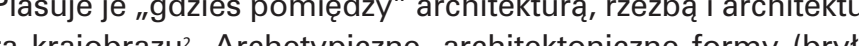
ą krajobrazu. Archer niajc historycze wydazenta wpisuja sie w przeznaczente

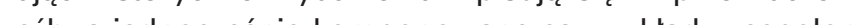
rzezb, a jednoczes wor zen" - implikujace sca no - "komponowane - implikjace scalonie - nie wystarcza jednak do schawiska wiska naturalnego. Natura jest tu elementem uzupelniającym architektoniczne struktury, a jednoczesnie stanowiącym ich antynomię, dopelniając utworzoną przestrzen poprzez przeciwienstwo dziela Boskiego i konstrukcji ludzkiej ręki, a kontras pomiędzy naturą i dziełem ludzkim jest nieodłączną cechą genius loci. Duch miejsca to relacja pomiędzy człowiekiem i światem, przy czym natura była pierwsza. Pejzaż, terytorium stopniowo przeistacza się w „pismo, historię, literaturę”.

2. Narracja

Mimo wykorzystywana przez Daniego Karavana lapidarnych form, w pracach artysty bardzo czytelna jest indywidualnie kreowana narracja. Narracja prac Karavana prowadzona jes przez rzeźbiarza na dwóch poziomach: uniwersalnym i jednostkowym - osobistym. Wywiedzione z tych dwóch pól środki narracyjne spajają obie „opowieści”: wątki oparte na życiu osobistym rzeźbiarza wpisuja się w uniwersalna symbolike a ekumeniczne archetypy - powiazane z symbolika odczyty wana przez zwiedzajacych - znajduja swoje odzwierciedlenie w jego indywidualnej autobiografii. Juhani Pallasma schaw jego indy do metody kreacii Dani Karavana:

Myśl artystyczna nie jest wyłącznie pojęciową czy logiczna dedukcja; implikuje ona egzystencjalne rozumienie i synteze przeżytego doświadczenia, które łączy w sobie percepcje, pamięć czy pragnienie. Percepcja łączy pamięć z tym, co faktycznie postrzegamy, i w rezultacie nawet zwykłe doznania zmysłowe stają się złożonymi procesami porównywania i oceny." W poszukiwaniu systematyki środków narracyjnych artysty sięgnąć można do katalogu z wystawy Daniego Karavana w Międzynarodowym Centrum Kultury Krakowie ${ }^{5}$. Prace rzeźbiarza pogrupowane tu zostały według rozdziałów, których tytuły odnoszą się do zasadniczych punktów "opowiesci" Karavana, trafnie je charakteryzując: Makom - „esencja miejsca", "pasaże, drogi, osie", "przeptywy", "powtórzon prawa”, , "poza definicjami" oraz "teatr form".

Kluczowe dla działania Karavana jest pojęcie Makom6, w którego wykorzystywaniu spaja się filozofia twórczości rzeźbiarza. Makom to jednocześnie obszar lub miejsce (przestrzeń) zajęte przez ludzi lub takie, ktore potencjalnie moze zostac or temporary - scattered around the world. One should also emphasize Dani Karavan's Jewish or gin, which constitutes an important contribution ewish culture to his work.

Karavan's installations are a space with a distinctly architectural expression. The sculptor himself sculpture with nat as: environmental-ste-specificthe same time, the artist emphasizes that he cannot specifically assign his works to a single field of art. He places them "somewhere in between" architecture, sculpture and landscape architecture2. Commemorating historical events, archetypical architectura forms (elementary solids, walls, columns, roads, porticos, etc.) fulfil the purpose of sculptures, bu at the same time they are integrated (composed) into systems combined with elements of the natura merging - The term "composing" - which implies relationship between Karavan's forms and the elements of the natural environment. Nature here is an element that complements architectural structures, but at the same time it constitutes their antinomy completing the created space with the opposite of God's work and the construction of the human hand. The contrast between nature and the manmade work is an inherent feature of the genius loci. The spirit of a place is the relationship between ma and the world, but nature was first. Landscape, territory is grad
literature" 3 .

\section{Narrative}

Despite the lapidary nature of forms used by Dani Karavan, the individually created narrative is very
clear in the artist's works. The narrative of Karavar's wons is constructed by the sculptor on two levels: universal and individual - personal one. The narrative means derived from these two fields unite both "stories": threads based on the sculptor's personal life are part of the universal symbolthe symbolism interpreted by the visitors - are reflected in his individual autobiography Juhani Pallasmaa characterized the connection of the personal and general universe with the creation of works of art in a way that is congruent with Dan Karavan's method of creation:

An artistic thought is not merely a conceptual or logical deduction, it implies an existential undertanding and a synthesis of lived experience that uses perception, memory and desire. Perception fuses memory with the actual percept, and conse plex processes of comparison and evaluation." Looking for the taxonomy of the artist's narrative means, one can refer to the catalogue from the exhibition of Dani Karavan's works at the Intern tional Cultural Centre in Kraków $w^{5}$. The works of the sculptor are grouped here according to chapters whose titles refer to the essential points in Karavan's "story", aptly characterizing them: Makom "the Essence of Place", "Passages, Roads, Axes", 
wgłębienia w posadzce placu - zegar słoneczny oraz ziggurat. Te elementy sa uniwersalnymi symbolami we wszystkich właściwie kulturach. Założeniem artysty było wpuszczenie między nie widzów i pozwolenie na swobodne interakcje między człowiekiem i rzeźbą-architekturą oraz naturą. Wiatr, światło słoneczne, woda, trawa i drzewo oliwne wymieniane sa jako elementy składowe kompozyciji2. Drzewo oliwne, które umieszczone zostato wewnatrz rozszczepionej koputy, jest stale pojawiajacym sie u Karavana motywem narracyinym. Mimo stosowania form zaczerpnietych z katalogu bryt goo metrycznych i archetypów architektonicznych, Karavan uzo-

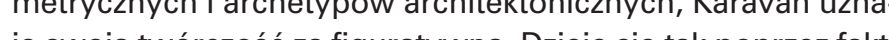
jez iz nie moze on is za figuz lyw

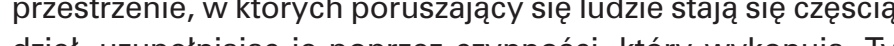
dziet, uzupelniajac je poprzez czynosci, Ktory wykonuja. Ty genius loci: uczynienie z przestrzeni partnera bytowania"14.

\section{Natura}

Geometrycznym kształtom w każdej instalacji Karavana towarzyszą powierzchnie zielone i drzewa oraz zbiorniki i cieki wodne. Rzezbiarz jest zdania, iz to z natury pochodzą wszystkie znane ludziom elementy. Pierwiastki naturalne $w$ rzeźbach

\section{5. Dani Karavan, Passages - whotdzie Walterowi Benjaminowi, Portbou
(1994). Żródto: Dani Karavan. Esencia miejsca. The Essence of Place kat} (1994). Zrodto: Dani Karavan. Esencja miejsca. The Essence of Place, ka
wyst., Miedzynarodowe Centrum Kultury w Krakowie, czerwiec-wrzesie
2015, Kraków 2015

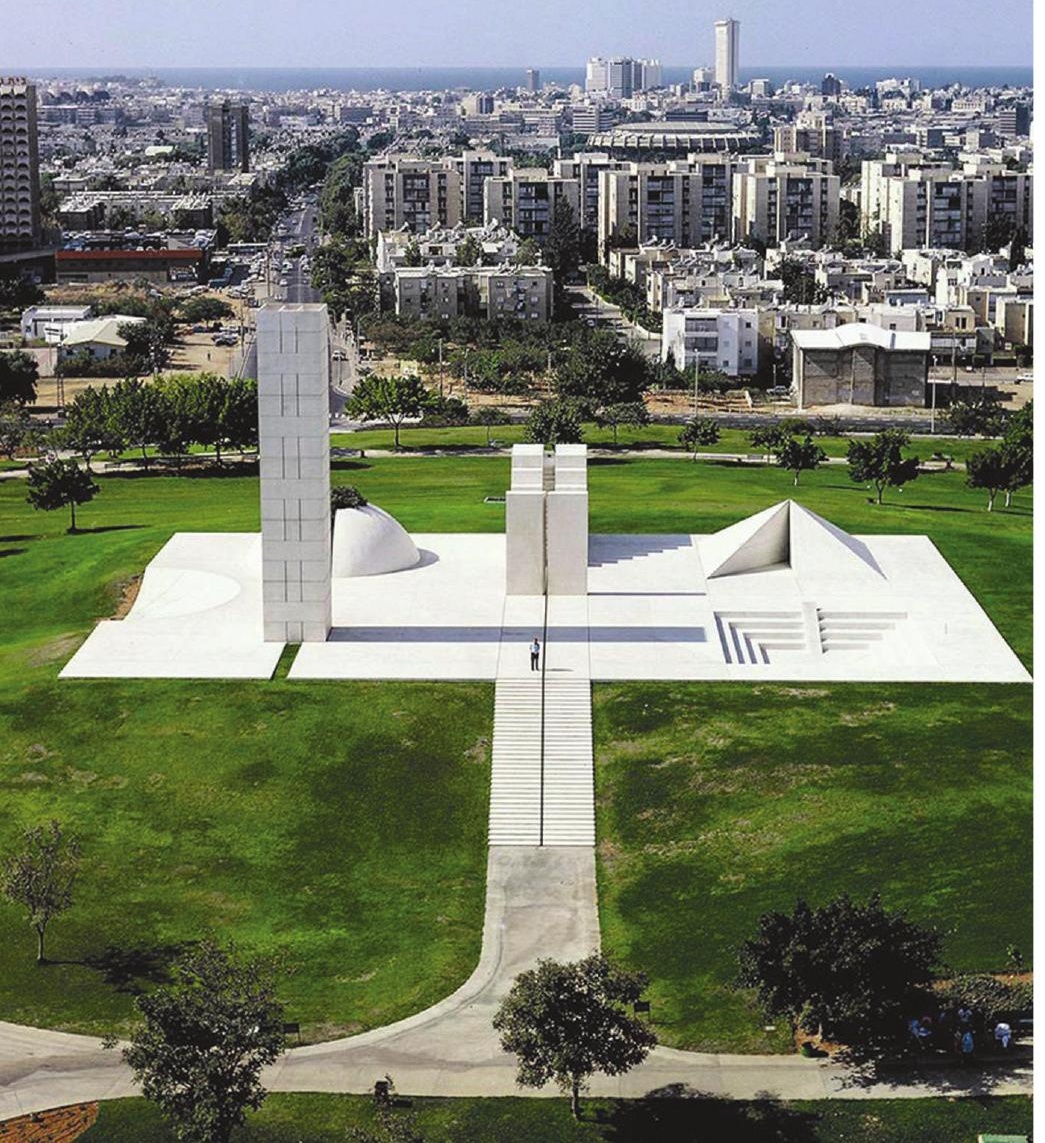

a place", defined as the "dynamic relationship of the earth and life

Kikar Levana (1988) was constructed on the hil above Tel Aviv as a tribute to the builders of the city and at the same time the Bauhaus style. White a cut wall - are arranged on the White Square (as this is how the name of this place is translated) a $30 \times 50 \mathrm{~m}$ concrete rectangle. They are accompanied by hollows in the floor of the square - a sundial and a ziggurat. These elements are universa symbols in all cultures. The artist intended to le the viewers in between them and allow for free in teraction between man, sculpture-architecture an nature. Wind, sunlight, water, grass and an olive tree are listed as constituent elements of the composition ${ }^{12}$. The olive tree, which has been placed in Karavan's work.

Despite the use of forms derived from the cataDespite of geometrical solids and architectural catatypes, Karavan regards his creative work as figurative one. This is due to the fact that it cannot exist without people ${ }^{13}$. The creations are designed as spaces in which moving people become part of the works, complementing them through the activities they perform. Thus, the artist introduces another postulate that characterizes genius loci: "turning space into a partner of existence"114.

\section{Nature}

Geometric shapes are accompanied by green surfaces and trees as well as reservoirs and watercourses in every Karavan's installation. The sculptor believes Natural elements in the Israeli sculptures are perceived not only by all senses rather than the sense of sight only. Greenery, water and fauna are also to be heard, touched and smelt here for full reception of the work. Landscape topography and natural ligh are important components of his creation.

the Socialism in Berlin's Tiergarten is a memoria commissioned by the German Bundestag and located next to its headquarters. Karavan provides a detailed description of the process in which he shaped the project ideologically. Limited space devoted to the structure rendered it impossible to build a tower or an obelisk as they would generate excessive accumulation of tourists. Therefore visitist used water as a method of separating the visitors and dispersing them on a larger area. The surroundings: sky, trees, the Reichstag and spectators, and all the reflected elements become components of the Sinti \& Roma Memorial. In this way visitors are also part of it. Dani Karavan recalled the theory which says that water has memory and everything that is reflected in it will be remembered forever. The sculptor describes the composition as a place of pain and memory One more natural element is an important part
of the installation, and its source is the Sinti and
Izraelczyka percepowane są nie tylko przez zmysł wzroku, także zostać usłyszane, dotknięte i powąchane dla pełnego odbioru dzieła. Istotnymi składnikami tworzenia są topografia krajobrazu oraz światło naturalne.

Sinti and Roma Memorial (2012) czyli Pomnik Pomordowanych Sinti i Romów Europy, Ofiar Narodowego Socjalizmu w berlińskiej dzielnicy Tiergarten to pomnik na zlecenie niemieckiego Bundestagu, ulokowany obok jego siedziby. Kawavan szczegótowo opisuje proces ideowego kszatowa- Kaprojektu Ogra projeki Ore byt duże nagromadzenie turystów. Artysta posłuzył się więc wodą jako metodą odgrodzenia zwiedzających i rozproszenia ich na wiekszym terenie. Okrągly staw niczym

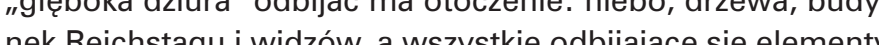
nek Reichstagui widzow, a wszysthe odbijające się elementy stają się elementami składowymi Sinti and Roma Memorial. $W$ ten sposób również zwiedzający są jego częścią. Dan Karavan przywołal teorię, zgodnie z kórą woda ma pamięc - a wszystko, co się w niej odbije zostanie zapamiętane na wieki. Rzeźbiarz określa kompozycję mianem „miejsca bólu i pamięci" ${ }^{\prime \prime}$

Jeszcze jeden element naturalny jest istotną częścią składowa instalacji, a jego zrodłem są cmentarze Sinti i Romów, tradycyjnie pozbawione grobow i jakichkolwiek tablic lub innych elementów okreslających miejsce konkretnych pochówków. Zielone pola porastają ląkowe kwiaty. Niewielki metalowy trójkąt w sadzawce berlińskiego pomnika symbolizuje trójkąt, na którym niesiono ciało do pochówku. Na nim umieszczono łąkowy kwiat. Codziennie o tej samej porze trójkąt zanurza się i wynurza ze świeżym kwiatem.

Tekst i muzyka są także elementami tego pomnika. Tekst w postaci wiersza Auschwitz romskiego poety Santina Sp nellego, uwiecznionego na obrzeżu zbiornika, nazw obozów koncentracyinych i miejsc zagtady wyrytych na fragmentach granitowych plyt na otaczającym sadzawkę trawniku oraz 列 colack

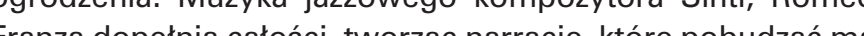
reystie zmysty.

Ważnym naturalnym elementem symbolicznym dla Dani Karavana jest drzewo oliwne. W znaczeniu uniwersalnym symbolizować ma ono pokój (drzewo to jest istotne dla Izraela) a odniesieniu do biografii artysty - zapamiętane z dzieciństwa stare drzewo-„„przyjaciela", przesadzone przez jego ojca, architekta krajobrazu, na podwórze rodzinnego domu rzeźbiarza. Na dziedzińcu siedziby UNESCO drzewo oliwne jest elementem instalacji Tolerance Square (1996), posadzojeste ne na niewielkim pagórku i otoczone okragłą, betonową ławką. Obok, na kamiennej scianie w 10 językach wyryte zostały pierwsze sentencje z konstytucji UNESCO: Ponieważ wojny rodzą się w umysle człowieka, równiez w umyśle człowieka dojrzec powinna sprawa obrony pokoju. Tu takze woda jes kolejnym elementem kompozycji - spływa z wolnostojącego walca kolumny i opływa zielone wzniesienie. Istotny jest
Roma cemeteries, traditionally devoid of graves, gravestones or any other elements defining the site of particular burials. Green fields are covere with meadow flowers. A small metal triangle in the pool of the Berlin monument symbolizes the trigle on which mody was caried to its buria day, A the same time, the triangle submerges and emerges with a fresh flower.

Text and music are also elements of this mon ment. A text in the form of a poem "Auschwitz" by Roma poet, Santino Spinelli, immortalized on the edge of the pool of water, names of concentration and extermination camps engraved on fragments of granite slabs on the lawn surrounding the pond and the most important dates and statements regarding the genocide of the Sinti and Roma imof Sinti jazz composer, Romeo Franz, The music the whole by creating a narrative that is to stimulate all senses.

An important natural symbolic element for Dan Karavan is the olive tree. In the universal sense, is meant to symbolize peace (this tree is significan for |sraell), and in relation to the artist's biography a "friend" remembered from the childhood - an old tree replanted to the yard of the sculptor's family home by his father who was a landscape architect. In the courtyard of WNESCO headquarters, the olive cular concre benctitus con of Tolerance installation (1996). Next to it the first words of the UNESCO constitution were engraved on the stone wall in 10 languages: "Since wars bein in the minds of men, it is in the minds of men that the defenses of peace must be constructed". Water is another element of the composition also here - it flows from a free-standing waltz of the column and surrounds the green hill. Its sound is important - a narrow concrete gutter does not produce spectacular visual efects. The composition fom cultures that once inhabited the territory of Israel. In the Ohel (Tent) project at Shebe Hospital in Tel-Hashomer (1991), an olive tree and concrete benches are located inside the light concrete shell of the "broken" pyramid, resembling Kikar Levana. The tree planted in the middle of a semi-circular dome on the White Square is to grow with time and fill the crack, thus combining the work of man and nature - and then it will transform into a symbol of

In some of Karavan's installations natural elements between man made art and naturis is reved The forms shaped by a man (sculptor) are embedded in the natural landscape - even if it happens in the city. An example here can be Karavan's largest ongoing project - the monumental Axe Majeur in the Parisian suburb of Cergy-Pontoise. The sculptor delimited a 3-kilometre axis and designed 12 spatial dominants along in (recognizing the number 12 as symbolic, referring to human existence). The starting point of the axis is the square surrounded 
jej dźwięk - wąska, betonowa rynna nie wywołuje widowiskowych efektów antycznych kolumn pochodzacych z kultur zamieszkujących kiedyś teren Izraela. W projekcie Ohel (Namiot) w Shebe Hospital - Tel Hashomer Ramat Gan (1991) z kolei drzewo oliwne oraz betonowe ławki znajduja się wewnątrz betonowej, jasnej skorupy "przeprutej" piramidy, podobnie jak na Kikar Lewana. Drzewo posadzone w środku pótkolistej kopuły na Białym Placu z czasem ma sie rozrosnać i wypetnić szczeline taczac Placu z czasem ma sie rozrosnć i wyphić szcz la lacząc tolerancji i akceptacji16.

W części instalacji Karavana elementy naturalne wkomponowane są w rzeźby, ale w innych relacja dzieła ludzkiego i natury jest odwrotna. Tam formy kształtowane przez człowieka

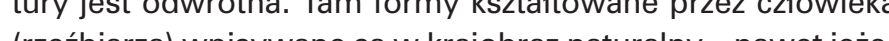

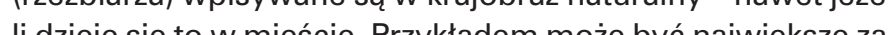
ti dzieje się to w miescie. Pry kladom noż być najwększe zatożenie Karavana - moju Pryle Majeur w podparyskiej miejscowości Cergy-Pontoise. Rzeźbiarz wyznaczył tu 3-kilometrową oś, na ktorej zaplanował 12 dominant przestrzennych (uznając liczbę 12 za symboliczna, odnoszącą się do ludzkiej egzystencji). Oś, która rozpoczyna się na placu osiedla projektu Ricardo Bofilla, nawiązywać ma do tradycji XVII-wiecznych ogrodow Le Notre'a oraz wielkich, przestrzennych osi francuskich (jak w Paryżu lub Wersalu). Umieszczone na niej elementy $w$ otoczeniu lesistego krajobrazu i jeziora to wielkoskalowe formy o mocnym wyrazie.

Oprócz fontann (np. fontanna ze wodami ze źródeł geotermalnych na Esplanadzie Paryskiej) i przestrzeni zieleni urządzonej (wiążący zieleń urządzoną części mieszkalnej z bardziej dzika Ogród Praw Człowieka Pierre'a Mendèsa, w którym istotna rolę odgrywają drzewa oliwne oraz sad owocowy poświęcony Pisarro i innym impresjonistom, gdzie prezentowana jest natura zmienna $w$ każdej porze roku) $z$ zielenią $i$ woda powiazzane sa tu: scena i amfiteatr nad jeziorem, Astronomiczna Wyspa - obecnie nieukończona, schronienie dla miejscowe fauny i flory - czy 250-metrowy, czerwony, pieszy most taczacy brzegi basenu wodnego (później ma on także dostrá czący brzegi basenu wodnego (pozzniej ma on także dotrzeć do Astronomiczneej Wyspy), czy Piramida na wodach jeziora. dzia. Betonowa konstrukcja ze schodami (współczesna waria-

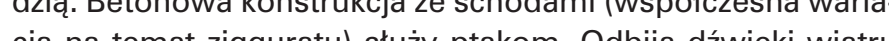
cja na temat ziggue i wody, kre zace nur role w Axe Majeur odgryaja tez rozlegle widoki. Calosc zaa z Tarasu - gigantycznych betonowych schodów - rozciąga a z Tarasu - gigantycz
się panorama regionu.

\section{Pustka}

Relacje rzeźby $z$ naturą w dziełach Karavana prowadzą do osiąganej przez artystę pustki. Szczególnie widoczna jest ona w jego realizacjach usytuowanych w Japonii. Jednocześnie dla osiagnnięcia tej pełnej znaczeń pustki (ma) konieczne jest zastosowanie lapidarnych środków, połączonych (znowu) $z$ naturą - krajobrazem. Istotne jest także utworzenie elementu "wycofania" - wymknięcie pewnej przestrzen

Droga do ukrytego ogrodu w Parku Sztuki w Sapporo (1999) to forma "drogi-przejścia", w ktorej charakterystyczne dla kul- by residential buildings designed by Ricardo Bofill that is to refer to the tradition of the $17^{\text {th-century }}$ gardens of Le Notre and the grand spatial Frenc axes (as seen in Paris or Versalles). The elements that are placed on the axis in the surrounding of forms with a strong expression

In addition to fong expression. ters from hot springs on the Esplanade de Paris and cultivated green areas (the Garden of Human Rights Pierre Mendès France, whose olive tree and fruit orchard dedicated to Pissarro and other Impressionists play a significant role, combines the greenery of a residential part with a more wild one and presents changeable nature in all seasons there are also other elements connected with greenery and water: the stage and amphitheatre by the lake, the unfinished Astronomical Island - the 250-metre long red pedestrian bridge connecting the shores of a pool of water (it is to reach the Astronomical Island in the future) and the Pyramid on the waters of the lake. This extraordinary element is accessible only by water - by boat. The concrete structure with stairs (a modern variation on the theme of a ziggurat) serves birds. It reflects the sounds of wind and water, creating a natur light-sound spectacle.

Extensive views also play an important role in Axe Majeur. The entire project spans between points of stairs - offers a panoramic view of the region.

\section{Emptiness}

The relationship between sculpture and nature in Karavan's works leads to the emptiness the artist achieves. It is particularly visible in his projects constructed in Japan. At the same time, to achiev this meaningful emptiness, it is necessary to use concise means, connected (once again) with nature - landscape. It is also important to create space.

The Way to the Hidden Garden in the Outdoor Sculpture Park in Sapporo (1999) is a form of "path-passage" in which the issues of form and measure characteristic of Western culture were paired with the far-eastern understanding of the landscape and experience of space. The 300-meter trail is composed of the elements merged into the topography of the area: a spatial reflection of the Japanese ideogram of a gate, hemisphere covered with grass, a large-scale sundial, 7 rectangular prisms of gushing fountains, a 7-mete channel, another gate and 8 concrete benches in the tree-sheltered area of the Hidden Garden. All elements, situated in the green of grass and trees, are white. An important role here is played by water in a variety of forms - fountains, stream and ice, remaining under the cone's surface throughout the year. This space is again received intensely with all senses, which becomes a work of nature.
The microphones among the trees collect bird tury zachodniej zagadnienia formy i miary powiązane zostały niem przestrzeni. 300-metrowy szlak tworza elementy wp sane $\mathrm{w}$ topografie terenu: przestrzenne odzwierciedlenie japońskiego ideogramu bramy, pokryte trawą półkule, wielkoskalowy zegar słoneczny, 7 prostopadłościanów fontann 7-metrowy stożek i meandrująca, betonowa forma obrzeż strumienia, kolejna brama oraz 8 betonowych tawek w ostonietym drzewami okregu Ukrytego ogrodu. Wszystkie ele

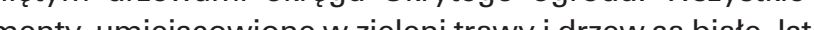
rent, umieju założeniu odgrywa woda - w różnych postato roz wa pod tal stzzk znowu jest to prze cry rok pozosta ancen-

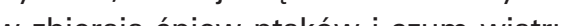

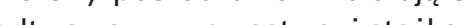

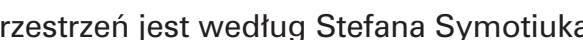
przestrzenią wolności - "wolności bytowania" ${ }^{{ }^{17}}$. „Aura” krajobrazu wiąze się z przeżywanymi nastrojami, a dyscyplina minimalistycznch, jednobarwnych form (np. w Sapporo) kreuj spokój, oderwanie, refleksje.

\section{System narracyjny}

Wymienione elementy rzeźb Karavana zawsze składają sie na jego autorski, spójny system narracyjny. Ten konieczny, odczytywalny jest np. w instalacji Passages w hiszpańskie miejscowości Portbou (1994) - miejscu śmierci Waltera Benjamina. Aby upamiętnić 50-lecie śmierci filozofa Karavan zaplanował kortenowy pasaż, wcięty w klif koło miejsca pochówku Benjamina oraz kilka minimalistycznych, również kortenowych elementów. Te formy zostały w sposób przemyślany wpisane w krajobraz, uzupełniając dzieło natury. „Drzewo oliwne i cyprysy, skały, woda (wraz z wirami i falami w niej), wiatr" przedstawiane są przez artyste jako składowe materiały projektu ${ }^{18}$. Obecny jest w Passages taki̇e schemat drogi - przeiścia. Umieszczone w pasaż Un dół kzifu w wrone w do klfu w stone morza prezomiczne wody pomien sa jezykach myś Benjomina: Trudniej uczcić jest pamieć bezumiench niz ludiz znanch. Konstrukcja historyczna poswie conn jest paz lucizi bezimych. Konstruczac historyczna poswié

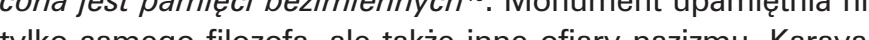
tylko samego filozofa, ale także inne ofiary nazizmu. Karavan w sposob dla siebie charakterystyczny uczynit to za pomoca lapidarnych środkow wyrazu i naturalnych zjawisk przyrody. Rdzawe, kortenowe elementy i surowy kamien w naturalnym otoczeniu - w zestawieniu z Morzem Śródziemnym - two rzą fenomenologiczne doswiadczenie, odbierane wszystkim zmysłami w poruszający sposobo. Schodząc krok po kroku, widz znajduje się w cichej, ciemnej, wywołującej klaustrofobiczne odczucia przestzeni, pozbawionej słonca - a więc zimnej. W połowie drogi jednak zadaszenie pasażu uryw się, otwierając widok na niebo. Na jej koncu natomiast przed widzem ukazuje się krajobraz kadrowany betonowymi stopniami i stalowymi ścianami. Wspinając się po schodach natomiast widzi on jedynie niebo, drugi koniec pasażu przesła- singing and the sound of the wind that are played inside the conical structure.

According to Stefan Symotiuk, the outer empty space is a space of freedom - "freedom of existence "17. The "aura" of the landscape is related to the moods being experienced, and the rigour of creates calmness, detachment and reflection.

\section{Narrative system}

The aforementioned elements of Karavan's sculptures always compose his own coherent narrative system. This necessary, although not always clear to

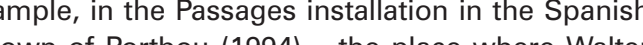
(19) where Walter death of the phil mark en steel passage wedged in the cliff near the burisite of Beniamin and a few other minimalist Corte steel elements. These forms have been thoughtfully embedded in the landscape, complementing the work of nature. The olive tree and cypress trees rocks, water (with whirpool and waves in it), wind are presented by the artist as component materials of the projectis.

The path-passage pattern is also present in Passages. The stairs placed in the passageway lead the visitor straight down the cliff towards the sea, wasts. The isea is visiche berind the pane of glass at the foot of the stairs, where Benjamin's thought is etched in several languages: "It is a more arduous task to honour the memory of nameless tha that of the renowned. The construction of history is consecrated to the memory of those who have no name" ${ }^{\prime 1}$. Not only does the monument honour the philosopher, but it also commemorates other victims of Nazism. Karavan did in his typical manner, using concise means of expression and natual phenomena of nature.

The rusty, Corten steel elements and raw stone ranean Sea - create a phenomenological experience that is perceived with all senses in a moving way. Descending step by step, the visitor enters a quiet, claustrophobic and dark space devoid of the sun - and therefore also cold. Yet, the roofing of the passageway breaks off halfway through, opening up to the view of the sun. At the end of it, a landscape framed with concrete steps and steel walls appears in front of the visitor's eyes. While climbing the stairs, he can only see the sky, scures the other end of the passageway. Stairs also lead to the burial place of the philosopher-5 Corten steel steps directing one towards the old olive tree. The whole is complemented by a Corten steel observation platform with a cube placed in its centre.

The name of the installation - Passages - is Karavan's tribute to the title of the philosopher's unfinished book, important to European culture, whic he had been working on until his death. 
nia bowiem kamienna ściana z miejscowego materiału. Do miejsca pochowku filozofa także prowadzą schody - 5 kortenowych stopni, kierujacych na stare drzewo oliwne. Całości uzupełnia kortenowa platforma widokowa z umieszczonym na jej środku sześcianem.

Nazwa instalacji - Pasaże - nadana została przez Karavaniego w hołdzie dla tytułu istotnej dla kultury europejskiej, nieukończonej ksiażki filozofa, nad ktora pracował aż do swojej śmierci.

\section{Podsumowanie}

Nieodłącznymi elementami instalacji Daniego Karavana są, oprócz kreowanych przez artystę form przestrzennych, zieleń i woda, a także elementy krajobrazu, takie jak topografia tere$\mathrm{nu}$, światło słoneczne, fauna czy wiatr. Wymienione elementy wykorzystywane sa nie tylko w wizualnym odbiorze przestrzeni, ale także percypowaniu innymi zmysłami: słuchem, powonieniem, dotykiem.

Stosowany przez Karavana zabieg wciaggania obserwatorów w czynne uczestnictwo poprzez doświadczanie rzeźb tak, że stają się oni elementami instalacji, "mnoży" poziomy prowadzonej przez niego narracji. Na uniwersalny i aubiograficzny jej poziom nakłada się wtedy również poziom autobiograficzny odbiorców. To może decydować o obecności genius loci w przestrzeni kreowanej przez rzeźbiarza.

Jeżeli genius loci definiowane jest jako "forma prze-myśliwania świata" ${ }^{\prime 20}$, to rzeźby Karavana można odczytać jako zapis tego przemysliwania. Jest to swoisty paradoks: fizyczne struktury - ukończone i utrwalone w kamieniu (ontologiczne rzeźba związana jest z trwałością) - mają być zapisem czegoś, co jest ulotne i utopijne, bo stanowi środek do nieosiagalnego celu. Jest to w swojej istocie stosowanie "wiedzy poetyckiej", czy też "poezii jako formy myślenia" ${ }^{\prime \prime}$, która oddaje istote więzi człowieka z miejscem.

Instalacje rzeźbiarza w swojej komemoratywnej funkcji spetniaja jeszcze więcej wyznaczików genius loci: obserwowanie historii popzez rzeczywistość i przywrócenie pierwotne kultury miejsca", troskliwośc spojzenia" umidaczniajaca Karava sie we wrazliwości tworzenia przestrzeni. Nawe

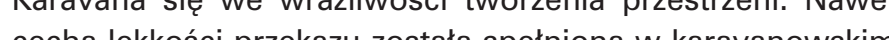
ceatrze form" - interakij izézb z odbiocami. Jednoczénie, "récbir ciagle poszuluje nowych form, niezadro odzwie

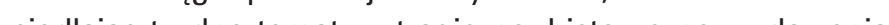
Spenic tra Spetniają one wiecc postulat "kitycznej refleks) na tema własnych [ludzkich - dopisek autorki] procedur".

ENDNOTES

1.Wywiad Z Danim Karavanem w. B. A 2 Dani Karavann Esencia miejsca. The Essence of Place, kat. wyst., Miedzynarodo-
we Centrum Kutury w Krakowie. czerwiec-wrzesien 2015, Krakó 2015, s. 106

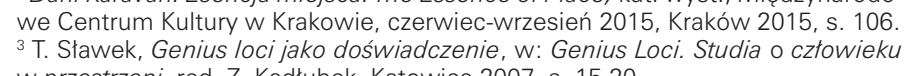

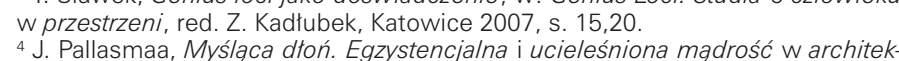

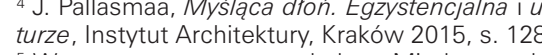

turze, Instytut Architektry, Krak
5 Wystawa prezentowana byta w Miedzynarodowym Centrum Kultury w Krako-
wie czerwiec-wrzesieñ 2015, kuratorzy: Hagai Segev, Monika Rydiger, wspótpraWie, czerwiec-wrzesień 2015 , kur
ca kuratorska: Noa-Caravan-Kohe

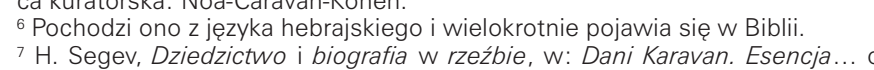

cit. s. 30 .
7. Conclusion

In addition to the spatial forms created by the artist greenery and water, as well as landscape elements such as topography of the area, sunlight, fauna and wind are inseparable elements of Dani Karavan's the visul perception of space, but also in the perception with other senses: hearing, smell, touch. Karavan's method of engaging observers in active participation through experiencing sculptures so that they become elements of the installation "multiplies" the levels of narrative developed by him. Thus, the autobiographical level of the recipients is superimposed on the universal and autobiographical level. This may determine the presence of genius loci in the space created by the sculptor If genius loci is defined as "a form of thinking the terpreted as a record of this thinking. This is a peculiar paradox: physical structures - finished and fixed in stone (sculpture is ontologically related to durability) - are to be a record of something that is fleeting and utopian, as it constitutes a means to a unattainable goal. It is essentially the use of "poetic knowledge" or "poetry as a form of thinking" 21 tha reflects the essence of man's connection with the

In their commemorative function, the sculptor's installations meet even more genius loci deterrestoring the "original culture of a place", the "ot tentiveness of a look" that is revealed in Karavan's sensitivity in creating space. Even the feature of the lightness of message was fulfilled in Karavan's "theatre of forms" - the interaction of sculpture with recipients. At the same time, the sculptor is constantly seeking new forms, often reflecting difficult themes - tragic historical events. They, therefore, meet the requirem their own [human - the author's annotation

\section{ENDNOTES}

and Urban Mith Dani Karavan in: B. Arandelovic, Public A 2 Dani Karavan. Esencja miejsca. The Essence of Place, exh

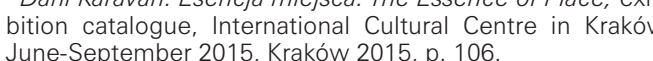
3. Stawek, Genius Ioci jako dosisiadcrenie, in: Genius Loci
Studia o cztowieku w przestrzeni, Z. Kadtubek, edd, Katowice Studia o cztowiek,
2007 , ph. 15,20 .

$4 \mathrm{~J}$. Pallasmaa, Myślacca dtoń. Egzystencialna i ucielosma p. 128 . ${ }_{5}^{5}$ The exhibition was held in

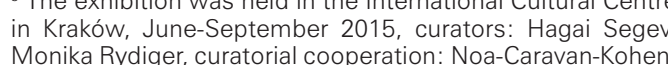
${ }^{6}$ It comes from the Hebrew language and appears a number of times in the Bible.
7 H. Segev, Dziedzictwo i biografia w rzeźbie, in: Dani Kara van. Esencija... op. citt, p. 30 . 3 . 8. L. Majewski, Kapiel w kamieniu, in: Tygodnik Powszechny
no. 26/2015. Makom. Dani Karavan. Esencja miejsca, p. 4

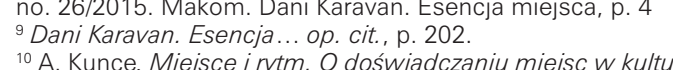
10 A. Kunce, Miejsce intm.tm. O doswividczaniu miejsc w kultu-
rze. in: Genius Ioci. Studia... op. cit., p. 114 . ree, in: Genius loci. Studia.... op.cit,. p. 114 .
11 . Stawek, op.cit., p. 7. This personality is to be associa-
ted with the landscape - an area formed out of physical and cultural forms. Characterizing genius loci, Tadeusz Stawek
refers to the analysis of the landscape and geography by
L.. Majewski, Kaplel w kamieniu, w: Tygodnik Powszechny nr 26/2015. Makom -Dani Karavan Esencia. op cit. s. 202

miejsc w kulturze, w: Genius loci.

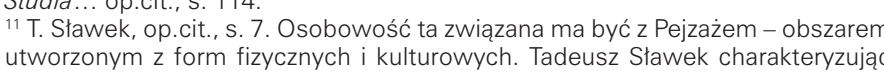
genius loci powotuje sie na analize pejzażu i geografii Carla O. Sauera.
12 Dani Karavan. Esencia... op. cit. S. 135.

${ }_{13}^{1}$ lbidem, S. 49.
${ }_{14}$ T. Stawek, op.cit., S. 5 .

Wywiad z Danim Karavanem w: B. Arandelovic, op.cit., s. 339,340

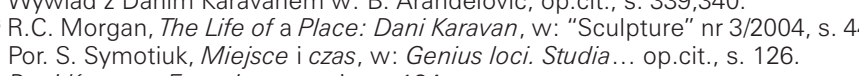
${ }^{19} \mathrm{Ibidem}$. Stawek, op.cit., s.

LITERATURA

11] B. Arandelovic, Public Art and Urban Memorials in Berlin, Springer 2018

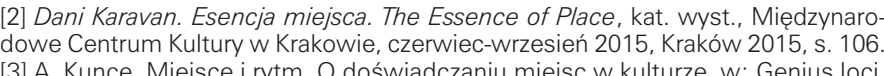
Studia... op.cit., s. 93-119.

any, and Japan w: Sculpthe, nr 8/2008, s. 44-49.

5] L. Majewski, Kapiel w kamieniu, w: Tygodnik Powszechny nr 26/2015 Ma

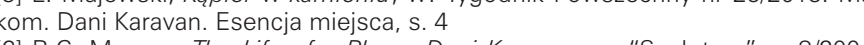

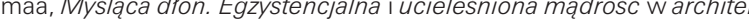

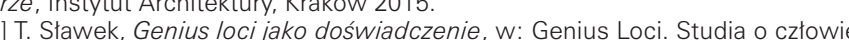

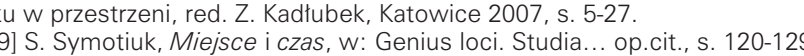

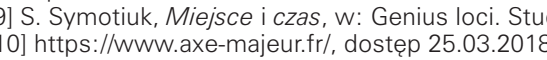
111 www.danikarvan. com_dostęp 25.03.2018.

[11] hitp://Mww.unesco.org/artcollection/NavigationAction.do? ?dOeuvre=2995
Dani Karavan. Esencia.... op. cit., p. p. 135.

${ }_{14}^{14}$ T. Stawek, op.cit,. p. 5 . R. C. Morgan, The Life of a Place: Dani Karavan, in: "Scut

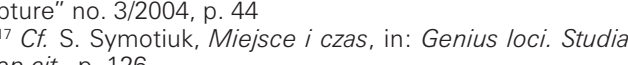

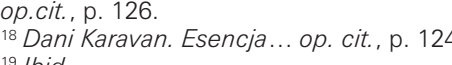

${ }^{20}$ T. Stawek, op.cit., p. 9
${ }^{21}$ bidd, p. 13.

BIBLIOGRAPHY

B. Arandelovic, Public Art and Urban Memorials in Berlin, Springer 2018, p. 341
[2] Dani Karavan. Esencja miejsca. The Essence of Place. exhibition catalogue, International Cultural Centre in $\mathrm{Kr}$ ków, June-September 2015, Kraków 2015, p. 106
[3] A. Kunce, Miejsce i rytm. O doświadczaniu miejsc w kuturze, in: Genius loci. Studia... op.cit., pp. 93-119 [4] A. Levine, Dani Karavan: New Work in France, Germany,
and apan in: Sculpture, no. 8/2008, pp. 44-49 15] L. Majewski, Kapiel w kamieniu, in: Tygodnik Powszech
ny no. 26/2015. Makom. Dani Karavan. Esencia miejsca, p. 4
IGI R. Morgan The Life of a Place: Dani Karavan, in: "Scul[6] R.C. Morgan, The Life of a
pture" no. $3 / 2004$, pp. $42-47$

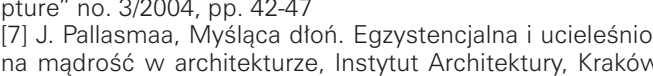

2015. [8] T. Stawek, Genius loci jako doświadczenie, in: Genius
Loci. Studia o czlowieku w przestrzeni, Z. Kadtubek, ed., Katowice 2007, pp. 5-27

i czas, w: Genius loci. Studia. 111 https:///Wwww.axe-majeur.ff/, retrieved on: 25.03 .2018

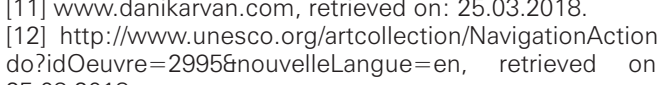

